\title{
Making The book of New Zealand women
}

\section{CHARLOTTE MACDONALD in conversation with Bill Renwick}

Bill Renwick : The Book of New Zealand Women, Ko Kui Ma te Kaupapa.: your title implies that your book will be comprehensive and perhaps definitive. How comprehensive is it?

Charlotte Macdonald: Though we called it The Book of New Zealand Women : Ko Kui Ma te Kaupapa, we are not in any way pretending that this is the only survey of New Zealand women, or that this is the selection of the most interesting or most important, or the most revealing set of portraits of New Zealand women's lives.

There are other books that could be put together in future. Another group of people would make a different selection, so it is not intended to be definitive.

Bill : The title also implies a significant Maori presence, and Merimeri Penfold is, with Bridget Williams and yourself, one of the co-editors. How have you handled the Maori side?

Charlotte: By talking a lot. This book was going to be about all women who had lived in New Zealand and of course that is Maori and Pakeha, as well as those from other ethnic groups. In the early stages of planning we talked to a number of Maori women and that came to a very happy first point when Merimeri Penfold, joined us as one of the editors on the project and she felt able to make that commitment and has continued to do so. The three of us have enjoyed working together on it very much indeed. Merimeri has directed and guided our work on this side of the book. That has developed through talking with a number of people, and working with three younger researchers: Cushla Parekowhai, Tui McDonald, and Raina Meha who have brought together much of the information about Maori women.

Our work on the Maori essays has gone in two directions. The first is a more conventional one which, like a number of Pakeha entries, has been to work from documentary evidence. The other direction has been to talk to descendants of women whom we were interested in including. This is the work that Cushla in particular has done, in talking to women in the community. The stories of women's lives have been recorded, so a number of articles are based on the families' recollections of their tupuna.

Bill: You talk about forebears, who then will be your earliest entry in the book?

Charlotte: We have some very early entries, some are figures from legend. Perhaps the earliest ones we can give any kind of date to are two women whose lives and portraits have been put together from archeological evidence. These are, first of all a woman who lived in eastern Palliser Bay in about the twelfth century; and the second is a woman who lived at Little Papanui Bay on the Otago peninsula in about the fifteenth/sixteenth century. These are portraits of women whose identity can never be known but we do know quite a lot about how and where they lived, for how long, and what they ate. They have been produced from archeological evidence by Helen Leach and Phillip Houghton.

\section{Bill: Are there any other anonymous entries?}

Charlotte: Yes, it might seem odd that in a book which is essentially a biographical dictionary we do have anonymous entries. Perhaps this illustrates how it is rather different from biography or conventional forms of biographical dictionary. We have two women who appeared simply as Miss $\mathrm{Y}$ and Miss $\mathrm{Z}$ before the Sweating Commission in 1889. They were two young laundry workers who were employed in the North East Valley in Dunedin. We don't know their identity and probably it would be impossible ever to discover what that was. They were identified in this way because of the fear of reprisal by their employers; of course a number of workers who gave evidence before that commission were similarly identified.

Bill: From anonymity to fame: how have you handled famous women such as Katherine Mansfield and Frances Hodgkins?

Charlotte: The book was never intended as a catalogue of famous or notable women. Selection has certainly not been on that criterion, it has been much wider. However, we felt that a book about New Zealand women could not omit people like Katherine Mansfield, Frances Hodgkins, Rita Angus, Mabel Howard, etc. So what we have done with those who are not only well known but who have also been the subject of recently published secondary works is to put in entries that are relatively short, thereby leaving space for other lesser known people. Each article will have a bibliographical note at the bottom so there will be an easy reference for people to go ahead and locate the main secon- 
dary sources. We would imagine that people wanting to know more about Katherine Mansfield's life would go to the major biographies, rather than to our book. But our article will provide a quick reference to dates and major works.

Bill: What about women who, until now, have been obscured by famous husbands?

Charlotte: I suppose one of the particular interests I had in selecting some women was to rescue those whose lives were extremely interesting and in many ways important, but who had been overshadowed by famous husbands. I think especially of people like Ellen Ballance who was married to John Ballance, Liberal Premier in the $1890 \mathrm{~s}$. She was important as an independent supporter of women's suffrage, (she was a member of one of the major English societies) and was a principal benefactor in the town of Wanganui where she spent most of her life. Or someone like Eliza Grey, the beautiful and estranged wife of Governor Grey, whose life is extremely revealing of many aspects of a nineteenth century marriage, and in many ways a tragic story. Or, of Hannah Barron, mother of Joseph Ward, whom Judith Bassett has written about. Hannah was an influential and extremely successful entrepreneur in Bluff. She shaped Joseph Ward's career and directed it as long as she was able. There are a number of others in this category: Millicent Baxter, Nell Tizard, Maud Pember Reeves.

Bill: What variety of women will we read about in The Book of New Zealand Women?

Charlotte: A huge number. We have looked for women whose activities were unusual, as the early Herstory diaries did, but equally at women whose lives reveal the common experience. I hesitate to use the word typical, because I am not sure that we know what a typical women's life was like, and it is an idea that we are not very comfortable with. The range of women in the book reveals much about the diverse elements and changing conditions in which women have lived. It sounds rather vague perhaps but I think people will be surprised at who is in there and what they have done.

Bill: In the seminar at the Stout you referred to the book as 'an alternative history of N.Z'. In what sense does it start to outline the case for an alternative reading?
Charlotte: Our principal intention in putting this book together was to produce an alternative history of New Zealand, i.e. a record of the lives of a number of New Zealand women. We believed it would be some time before primary research was sufficiently advanced to support a detailed survey of the history of women in New Zealand but we felt biographical investigation had gone a lot further and was one way of putting together some sort of overall picture. At this point, still being fairly close to the project, I am not sure that I quite know what that alternative shape is, and how successful we have been in producing it, - it might be something which I feel more able to see in a year's time or so.

The lives of women featured in The Book provide new information and a wide base from which to review the periodisation of New Zealand's past. Women's history questions the appropriateness of commonly accepted eras usually marked by wars and political events for describing significant changes in women's lives. The onset of fertility decline, for example, can be argued to have been of greater impact on society than the election of a Liberal government at the end of the nineteenth century. The women in The Book whose lives span the period from the 1880 s to the 1930 s certainly reveal a good deal about this major transition.

Another thing which is very apparent in looking at those women whose activities cover the interwar years is that the 1920s and 1930s far from being a 'dark age' for women, were a time at which there was a considerable amount of political activism. This did not necessarily take the form of an explicitly feminist movement, but rather, was one in which women became engaged in existing political and professional organisations. I think here of Ellen Melville who has become almost a 'lost' figure from the 1920 s and 30s. Sandra Coney has written about her for The Book. There was the whole working women's movement which came out of the Depression; the group of new women's organisations founded in the mid 1920s: Country Women's Institutes, Women's Division of the Farmer's Union (later WDFF), Federation of University Women - and there were others. How far this has contributed towards creating an alternative or new history of New Zealand is hard to tell at this stage, though I think we have gone a long way towards making such a goal possible. 